SŁawomir Dorocki, Agnieszka Świętek

Uniwersytet Pedagogiczny, Kraków, Polska

\title{
Uwarunkowania rozwoju usług opartych na wiedzy na przykładzie analizy działalności gabinetów stomatologicznych w Polsce
}

\section{Determinants of the Knowledge-Based Services Development, on the Basis of the Analysis of Dental Business in Poland}

\begin{abstract}
Streszczenie: W artykule autorzy poddali analizie uwarunkowania rozwoju działalności gabinetów stomatologicznych w Polsce, jako przykład przedsiębiorstw świadczących usługi oparte na wiedzy. W tym celu przeprowadzili badania i analizy, których wyniki przedstawili w poniższym artykule. W tekście potwierdzono „oparcie na wiedzy” zawodu stomatologa, poprzez analizę nakładów finansowych i czasowych przeznaczonych przez dentystów na podnoszenie kwalifikacji zawodowych. W tekście przedstawiono wyniki własnych badań ankietowych, przeprowadzonych na grupie 60 lekarzy stomatologów. Ponadto dokonano analizy sytuacji stomatologów na rynku pracy w porównaniu z innymi przykładowymi ,zawodami opartymi na wiedzy. W drugiej części tekstu skupiono się na analizie barier w rozwoju prywatnych gabinetów stomatologicznych. W części tej poddano analizie oferty szkoleniowe skierowane do osób zamierzających założyć własne gabinety, jak i prowadzących własną działalność. Dokonano również analizy kosztów związanych z uruchomieniem własnego gabinetu stomatologicznego. W wyniku badań i wywiadów autorom udało się określić uwarunkowania jakie determinują funkcjonowanie rynku prywatnych usług stomatologicznych w Polsce. Według przeprowadzonych badań wykazano, że głównymi barierami w rozwoju tych usług są brak potrzebnej wiedzy na temat zakładania i prowadzenia własnej działalności gospodarczej, a w drugiej kolejności brak funduszy na jej rozpoczęcie.
\end{abstract}

Abstract: In the article the authors analyzed the determinants of dental services' development in
Poland, as an example of knowledge-based services. For this purpose, they conducted tests and anal-
yses, whose results are presented in the article. They proved "knowledge base" of dental profession
by means of the analysis of dentists' financial and time investment. They presented the results of their
survey conducted on a group of 60 dentists, preceded by an interview with the owners of dental sur-
geries. They examined the situation of dentists in the labor market in comparison to other examples of
"knowledge-based professions," which showed that the unemployment does not affect this profession.
It cannot be said about other knowledge-based professions. The analysis of training offers for people
who want to start their own business provided some information about the scope of technical assistance
in setting up and running their own business which can be obtained from PARP, NIL and private train- 
ing companies. The authors carried out an analysis of the costs of starting dental practice. As a result of research and interviews, the authors were able to identify the factors which determine the functioning of dental services market in Poland. It turned out that the main barriers to the development of these services is surprisingly: the lack of knowledge about setting up a business, and in the second place, the lack of funds to start it.

Słowa kluczowe: działalność oparta na wiedzy, Polska, stomatologia, dentyści

Key words: business based on knowledge, Poland, dental business, dentists

\section{WPROWADZENIE}

Gospodarka oparta na wiedzy staje się dziś kolejnym, po postindustrialnym etapem w rozwoju gospodarczym świata (Borowiec, Dorocki, Jenner 2009). Zgodnie z raportem OECD opublikowanym w roku 1996, gospodarkę opartą na wiedzy zdefiniowano jako: ,gospodarkę bezpośrednio opartą na produkcji, dystrybucji oraz użyciu wiedzy i informacji” (OECD 1996: 7). Współcześnie, obserwując zmiany na światowych rynkach, należy stwierdzić, że przytoczone pojęcie wymaga redefiniowania. Bliższą współczesności definicją, zdaniem autorów, byłoby stwierdzenie, że: gospodarka oparta na wiedzy i informacji, determinuje produkcję dóbr i usług oraz ich dystrybucję. Zaproponowana przez autorów definicja stawia wiedzę i informację na pierwszym miejscu, jako priorytet w rozwoju gospodarczym, który determinuje w dalszej konsekwencji produkcję oraz dystrybucję wytworzonych dóbr i usług. Definicja ta stawia również dobra i usługi jako równorzędne efekty działalności gospodarczej, odchodząc od tradycyjnego nastawienia gospodarki na produkcję wartości materialnych. W sektorze usług wiedza i informacja pełnią dwojaką funkcję. Z jednej strony wiedza i informacja mogą być produktem finalnym i być bezpośrednio wystawiane na sprzedaż. Takie usługi świadczą wszelkie przedsiębiorstwa doradcze, gdzie udzielana przez fachowców rada i informacja ma swoją konkretną cenę. Z drugiej strony, wiedza i informacja może być nie tyle produktem samym w sobie, co czynnikiem niezbędnym do wykonania określonej zaawansowanej usługi. W obu przypadkach mamy do czynienia $\mathrm{z}$, usługami opartymi na wiedzy”. Przykładem takich usług z wykorzystaniem wiedzy są - wybrane przez autorów do analizy - usługi stomatologiczne. Na ich przykładzie autorzy podjęli rozważania na temat uwarunkowań jakie wpływają na możliwości rozwoju usług opartych na wiedzy. $\mathrm{W}$ analizie pochylono się w szczególności nad czynnikami bezpośrednio wpływającymi na chęć i możliwość rozpoczęcia działalności usługowej „opartej na wiedzy” przez potencjalnych przedsiębiorców.

Przedmiotem niniejszego artykułu i jednocześnie podjętych przez autorów badań są uwarunkowania rozwoju usług opartych na wiedzy, na przykładzie analizy działalności prywatnych gabinetów stomatologicznych w Polsce. W analizie ujęto głównie uwarunkowania rozwoju działalności gabinetów stomatologicznych w Polsce, jako przykładu przedsiębiorstw świadczących „usługi oparte na wiedzy”. W pracy wykorzystano wyniki badań ankietowych przeprowadzonych przez autorów na grupie 60 lekarzy stomatologów. Ankieta poprzedzona 
była pogłębionym wywiadem przeprowadzonym z przedsiębiorcami-dentystami prowadzącymi z powodzeniem od długiego czasu gabinet dentystyczny oraz posiadającymi doświadczenie w branży stomatologicznej i zdobywaniu środków unijnych na rzecz rozwoju swojej działalności. W analizie odniesiono się również do sytuacji stomatologów na rynku pracy w porównaniu z innymi przykładowymi ,zawodami opartymi na wiedzy”. Jako determinanty rozwoju usług dentystycznych w Polsce, w tekście poddano analizie oferty szkoleniowe skierowane do osób zamierzających założyć własną działalność gospodarczą oraz koszty związane z uruchomieniem i prowadzeniem własnego gabinetu stomatologicznego.

Przeprowadzone badania stały się dla autorów podstawą do wskazania głównych uwarunkowań rozwoju usług opartych na wiedzy, na przykładzie usług stomatologicznych.

\section{Znaczenie gospodarcze stomatologit w Polsce}

Rozważania nad rozwojem usług stomatologicznych w Polsce autorzy postanowili rozpocząć od przybliżenia czytelnikom wielkości rynku stomatologicznego w Polsce, jego znaczenia i współczesnych kierunków rozwoju. Zgodnie z raportem Naczelnej Izby Lekarskiej w Polsce na dzień 03.10.2012 r. liczba lekarzy dentystów wykonujących zawód wynosiła 33806 osób (strona internetowa NIL). Rynek gabinetów dentystycznych w Polsce jest zdominowany liczebnie przez gabinety publiczne. Niewiele ponad 30\% gabinetów z ponad 22 tysiąca działających na terenie naszego kraju, to gabinety prywatne. Przyglądając się jednak rzeczywistemu podziałowi rynku usług dentystycznych, należy stwierdzić, że sytuacja wygląda inaczej. Gabinety prywatne, pomimo, że stanowią zdecydowaną mniejszość, obsługują 54\% pacjentów korzystających z usług stomatologicznych w Polsce. Przyczyną takiego stanu rzeczy są prawdopodobnie głównie ograniczenia w wachlarzu usług oferowanych przez gabinety publiczne oraz odpłatność wielu podstawowych usług stomatologicznych oferowanych w zakładach publicznej opieki zdrowotnej. Niewiele specjalistycznych usług stomatologicznych jest w pełni refundowanych przez Narodowy Fundusz Zdrowia, a usługi o wyższym standardzie są odpłatne, tak jak w gabinetach prywatnych (NFZ finansuje pełne leczenie jedynie przednich, widocznych zębów). Wiele do życzenia pozostawiają w zakładach publicznych również dostępne terminy wizyt lekarskich. Przewagą gabinetów prywatnych jest zatem: dużo szerszy wachlarz świadczonych usług, powszechnie posiadana umowa z NFZ umożliwiająca refundację podstawowych usług (tak jak w gabinetach publicznych), znacznie łatwiejszy dostęp do usług i elastyczność w dopasowaniu terminów wizyt do klienta czy wreszcie nowocześniejsze wyposażenie gabinetów i estetyczniejszy ich wygląd (wbrew pozorom ważny dla klientów).

Stomatologia jest jedną z pierwszych branż medycznych, w której Polacy byli gotowi płacić za usługi z własnej kieszeni. Rynek usług stomatologicznych w Polsce stale się rozwija, dziś szacuje się, że na leczenie zębów w Polsce wydaje się około 8 mld zł rocznie (Gazeta Wyborcza 27.02.2012). Polacy coraz częściej korzystają z usług stomatologicznych już nie tylko z konieczności, lecz również ze względów estetycznych. Rynek jest jednak nadal zdominowany przez usługi polegające na procesie standardowego leczenia, podczas 
gdy w krajach Europy zachodniej większość usług stomatologicznych polega na profilaktyce dentystycznej. Pomimo tego, wykształcenie dentystów i jakość świadczonych usług w Polsce nie ustępuje w niczym tym świadczonym w innych krajach wysokorozwiniętych. Efektem tego jest nie tylko rozwój w kierunku zaspokajania potrzeb polskich klientów, lecz również zagranicznych. Jednym z kierunków rozwoju rynku stomatologicznego w Polsce jest świadczenie usług stomatologicznych obcokrajowcom, przybywającym do Polski niekiedy wyłącznie w celu skorzystania z usług stomatologicznych. Dzieje się tak, gdyż w Polsce świadczone przez gabinety prywatne usługi cechuje wysoka jakość i stosunkowo niska cena. Przykładem niech będzie leczenie kanałowe. W Polsce cena takiego leczenia to koszt ok. 300-400 zł, w USA 1200\$, a w Wielkiej Brytanii 50-150£. Opisane zjawisko nosi nazwę denturyzmu, a o jego skali może świadczyć choćby fakt uruchomienia na Uniwersytecie Medycznym w Łodzi półrocznego kursu dla przewodników medycznych o tej właśnie nazwie. W zależności od regionu kraju zagraniczni pacjenci stanowią od 10 do 20\% wszystkich leczonych. Przykładem może być Szczecin, w którym działa prawie 800 gabinetów nastawionych na leczenie pacjentów z Niemiec (Dziennik Gazeta Prawna 20.02.2011).

Zarówno wskazane przykłady rozszerzenia rynku wewnętrznego (większa ilość pacjentów korzystających coraz częściej nie tylko z podstawowych usług, np. rozwijający się rynek implantologiczny), jak i powstawanie dla polskiej stomatologii rynku pacjentów zagranicznych powoduje, że stomatologia w Polsce jest usługą perspektywiczną. Zgodnie z prognozami, w najbliższym czasie nastąpi 10\% wzrost rynku usług dentystycznych w Polsce i w 2013 r. rynek ten ma osiągnąć wartość 10 mld zł (Dziennik Gazeta Prawna 16.02.2011). Dodatkowo w wyniku kryzysu następuje coraz większy spadek nakładów NFZ na usługi dentystyczne, co spowodowało, że udział wartości prywatnych nakładów na usługi dentystyczne wzrósł w 2011 roku do 78\% (Rynek usług dentystycznych w Polsce 2011. Prognozy rozwoju na lata 2011-2013). Można się zatem spodziewać, że rozwój prywatnych usług dentystycznych w Polsce będzie wykazywał tendencję wzrostową.

\section{Stomatologia JAKO USŁUGA SILNIE OPARTA NA WIEDZY}

Rozwój stomatologii obejmuje nie tylko poszukiwanie nowych rynków i wzrost wartości sprzedawanych usług, lecz nade wszystko wielowymiarowy rozwój wewnętrzny oparty na wiedzy. Świadczenie usług stomatologicznych w konkurencyjnych warunkach rynkowych wymusza na prowadzących działalność gospodarczą stałe dokształcanie kadry stomatologów, unowocześnianie sprzętu i stosowanych metod leczenia.

Zgodnie z danymi prezentowanymi w specjalistycznej prasie, stomatolodzy są grupą zawodową najwięcej inwestującą w dodatkowe szkolenia, kursy podyplomowe i certyfikaty. Co ciekawe, wyprzedzają pod tym względem menedżerów, pracowników marketingu czy IT, którzy są powszechnie postrzegani jako grupy zawodowe przodujące w korzystaniu z ustawicznego kształcenia. Rocznie dentysta na swoją edukację w Polsce i za granicą wydaje nawet 10-15 tys. zł, a rekordziści nawet 34 tys. za jeden kurs (Rogut 2011). Należy jednak zaznaczyć, że tak wysokie wartości nakładów przeznaczonych na samokształcenie mogą być 
wynikiem obowiązków nałożonych na lekarzy w 2000 r. przez NIL w postaci tzw. punktów edukacyjnych. System punktów wprowadzono w odniesieniu do lekarzy, którzy chcą prowadzić ewidencję przebiegu swojego doskonalenia zawodowego. System ten jest dobrowolny i nieobowiązkowy oraz dotyczy lekarzy, który uczestniczą w postępowaniu konkursowym na stanowisko kierownicze. System ten w mniejszym stopniu dotyczy zatem lekarzy dentystów prowadzących prywatne praktyki stomatologiczne, choć w pewnym stopniu może wpływać na decyzję o uczestniczeniu w szkoleniach i konferencjach.

Dowodami na prasowe doniesienia są również prowadzone na szeroką skalę aktualne badania wśród polskich lekarzy. W bieżącym roku, Instytut Filozofii i Socjologii PAN wraz z Ośrodkiem Studiów, Analiz i Informacji Naczelnej Izby Lekarskiej przeprowadziły wspólnie badania na grupie 837 lekarzy, w tym lekarzy dentystów, dotyczące rozwoju zawodowego tej grupy. Z opublikowanego na podstawie badań raportu „Możliwości i bariery rozwoju zawodowego lekarzy i lekarzy dentystów" (2012) wynika, że polscy lekarze w zdecydowanej większości widzą konieczność doskonalenia zawodowego przez cały okres praktyki zawodowej. Niemal $90 \%$ badanych lekarzy widzi swój dalszy rozwój zawodowy w uzyskiwaniu specjalizacji w wybranych dziedzinach nauki, a $80 \%$ wskazuje za celowe zdobywanie certyfikatów w wąskich dziedzinach medycyny. Dotyczy to również lekarzy stomatologów, rozszerzających coraz chętniej wachlarz świadczonych przez siebie usług, co potwierdzają oferty gabinetów stomatologicznych. Coraz częściej prywatne gabinety dentystyczne oferują połączenie podstawowej opieki stomatologicznej ze specjalistycznymi usługami, jak choćby chirurgią szczękową, protetyką czy ortodoncją. Niemal wszyscy badani lekarze wykazali, że planują i uważają za konieczne korzystanie z innych form kształcenia.

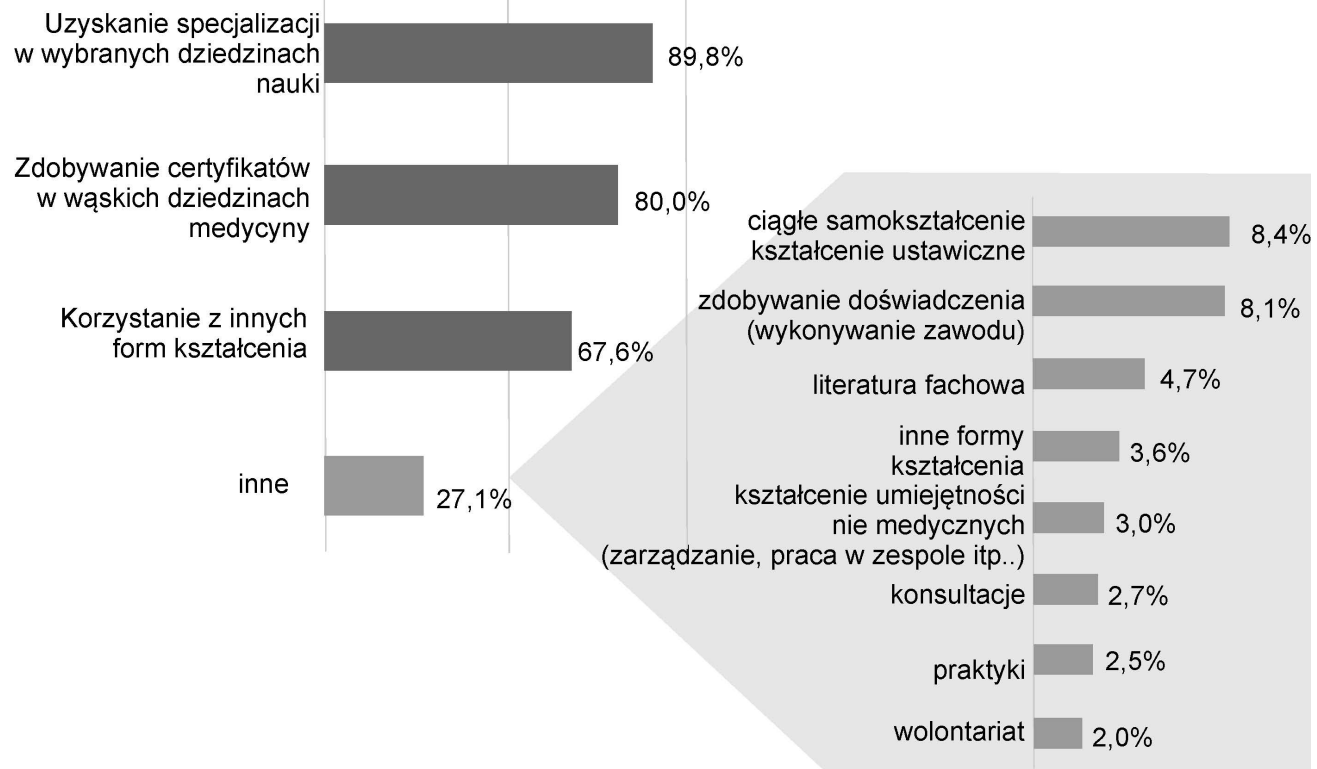

Ryc. 1. Stosunek badanych lekarzy i lekarzy stomatologów do doskonalenia zawodowego Źródło: raport PAN i NIL „Możliwości i bariery rozwoju zawodowego lekarzy i lekarzy dentystów” 
Najczęściej wymienianą wśród lekarzy formą kształcenia jest kształcenie ustawiczne $(8,4 \%)$, zdobywanie doświadczenia poprzez czynne wykonywanie zawodu $(8,1 \%)$ oraz czytanie fachowej literatury (4,7\%). Innymi, rzadko wskazywanymi przez ankietowanych lekarzy drogami rozwoju było zdobywanie umiejętności niemedycznych (w tym z zakresu zakładania własnej działalności gospodarczej), konsultacje z innymi lekarzami, odbywanie praktyk oraz uczestnictwo w wolontariacie (ryc. 1).

Wyrazem silnego oparcia na wiedzy usług stomatologicznych i potwierdzeniem ww. opinii są również zawarte w przytoczonym powyżej raporcie wyniki badania ilości czasu poświęcanego przez lekarzy i wysokości środków ponoszonych przez nich na doskonalenie zawodowe.

Wśród badanych lekarzy, w tym dentystów, niemal połowa stwierdza, że w przeciągu ostatnich czterech lat poświęciło na doskonalenie zawodowe dość dużo czasu (ryc. 2A). Niemal 14\% badanych poświęciło w tym okresie na kształcenie bardzo dużo czasu. Łącznie w badanej grupie stanowią oni 63,2\%. Niecała 1/3 lekarzy deklaruje, że ilość poświęconego czasu była niezbyt duża (32,4\%), a jedynie $4,4 \%$ badanych przyznaje, że poświęca na doskonalenie bardzo mało czasu, lub nie poświęca go wcale.
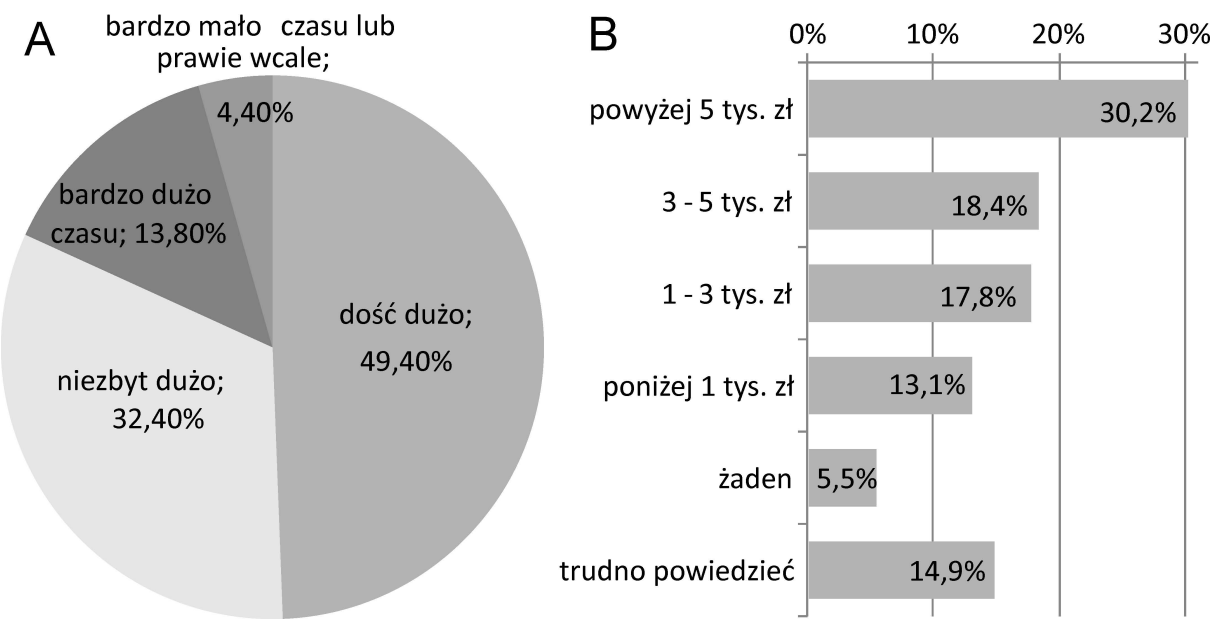

Ryc. 2. Określenie ilości czasu poświęconego w ostatnich 4 latach na doskonalenie zawodowe przez badanych lekarzy (A) i określenie wysokości wydatków badanych lekarzy na doskonalenie zawodowe w ostatnich 4 latach (B)

Źródło: raport PAN i NIL „Możliwości i bariery rozwoju zawodowego lekarzy i lekarzy dentystów”

Znaczne są również koszty ponoszone na doskonalenie zawodowe przez badanych lekarzy, w tym lekarzy dentystów. Najwięcej spośród badanych lekarzy $(30,2 \%)$ wskazuje, że w minionych 4 latach wydało na doskonalenie zawodowe powyżej 5000 zł (ryc. 2B). Około $18,4 \%$ lekarzy poniosło koszty w wysokości $3000-5000 \mathrm{zl}$, a $17,8 \% \mathrm{w}$ przedziale $1000-3000$ zł. Zaledwie 5,5\% badanych deklaruje, że nie przeznaczyło na ten cel żadnych własnych środków. Ponoszone przez lekarzy środki na doskonalenie zawodowe są zatem w przypadku większości z nich znaczne, a gdyby grupą badaną byli wyłącznie dentyści - zapewne byłyby 
one jeszcze wyższe. Wysokość ponoszonych przez dentystów i innych lekarzy kosztów czasowych i pieniężnych na rozwój jest kolejnym z dowodów na wysokie oparcie na wiedzy usług medycznych, w tym usług stomatologicznych.

\section{SYTUACJA STOMATOLOGÓW NA RYNKU PRACY W ZESTAWIENIU}

\section{Z INNYMI ZAWODAMI OPARTYMI NA WIEDZY}

Rosnące zapotrzebowanie na usługi dentystyczne w Polsce jest główną przyczyną rozwoju rynku stomatologicznego. Dzięki owemu zapotrzebowaniu, sytuacja lekarzy stomatologów na rynku pracy jest bardzo dobra. Zgodnie z raportem Departamentu Rynku Pracy MPiPS „Zarejestrowani bezrobotni oraz wolne miejsca pracy i miejsca aktywizacji zawodowej wg zawodów i specjalności w II półroczu 2011 roku”, zarejestrowanych bezrobotnych dentystów jest bardzo mało w stosunku do ich ogólnej liczby. Stopa bezrobocia w tej grupie zawodowej nie zbliża się nawet do poziomu $1 \%$, nie będzie więc ona przedmiotem rozważań autorów. Zgodnie z danymi MPiPS, pod koniec II półrocza 2011 r. zarejestrowanych bezrobotnych dentystów bez specjalizacji było zaledwie 75 . W przypadku dentystów posiadających specjalizację, o bezrobociu w ogóle ciężko mówić. Ilość zarejestrowanych bezrobotnych specjalistów wynosi kilka, lub kilkanaście osób dla poszczególnych specjalizacji. Wśród tych nielicznych przypadków, większość dentystów wcześniej pracujących, pozostaje bez pracy do 1 roku. Nie ma zatem cienia wątpliwości, że nawet ta wąska grupa nie jest zagrożona długotrwałym bezrobociem, a liczba zarejestrowanych wynika prawdopodobnie z naturalnych „migracji” pomiędzy miejscami pracy, lub specyficzną sytuacją osobistą poszczególnych bezrobotnych. Z przedstawionego zestawienia (tab. 1) wnioskować można również, że Urząd Pracy nie jest miejscem, gdzie pracodawcy poszukują potencjalnych pracowników.

Tab.1. Zarejestrowani bezrobotni lekarze dentyści w końcu II półrocza 2011 r.

\begin{tabular}{|c|c|c|c|c|c|}
\hline \multirow[b]{2}{*}{ Zawody i specjalności } & \multirow{2}{*}{$\begin{array}{l}\text { Zarejestrowani } \\
\text { bezrobotni wg } \\
\text { stanu w końcu } \\
\text { II półrocza } \\
2011 \mathrm{r} .\end{array}$} & \multicolumn{3}{|c|}{$\begin{array}{l}\text { W tym bezrobotni poprzed- } \\
\text { nio pracujący według czasu } \\
\text { pozostawania bez pracy }\end{array}$} & \multirow{2}{*}{$\begin{array}{c}\text { Liczba wol- } \\
\text { nych miejsc } \\
\text { pracy } \\
\text { i miejsc } \\
\text { aktywizacji } \\
\text { zawodowej } \\
\text { w końcu II } \\
\text { półrocza } \\
2011 \mathrm{r} . \\
\end{array}$} \\
\hline & & $\begin{array}{l}\text { do } 1 \\
\text { mie- } \\
\text { siąca }\end{array}$ & $\begin{array}{l}1-12 \\
\text { mie- } \\
\text { sięcy }\end{array}$ & $\begin{array}{l}\text { pow. } \\
12 \\
\text { mie- } \\
\text { sięcy }\end{array}$ & \\
\hline Lekarz dentysta & 75 & 8 & 56 & 5 & 1 \\
\hline $\begin{array}{l}\text { L. dentysta - chirurgia stomatolo- } \\
\text { giczna }\end{array}$ & 4 & 0 & 4 & 0 & 0 \\
\hline $\begin{array}{l}\text { L. dentysta - chirurgia szczękowo- } \\
\text {-twarzowa }\end{array}$ & 0 & 0 & 0 & 0 & 0 \\
\hline
\end{tabular}




\begin{tabular}{|l|c|c|c|c|c|}
\hline L. dentysta - epidemiologia & 0 & 0 & 0 & 0 & 0 \\
\hline L. dentysta - ortodoncja & 2 & 0 & 1 & 1 & 0 \\
\hline L. dentysta - periodontologia & 0 & 0 & 0 & 0 & 0 \\
\hline $\begin{array}{l}\text { L. dentysta - protetyka stomatolo- } \\
\text { giczna }\end{array}$ & 2 & 0 & 2 & 0 & 0 \\
\hline L. dentysta - stomatologia dziecięca & 1 & 0 & 1 & 0 & 0 \\
\hline $\begin{array}{l}\text { L. dentysta - stomatol. zachowawcza } \\
\text { z endodoncją }\end{array}$ & 16 & 1 & 11 & 3 & 1 \\
\hline L. dentysta - zdrowie publiczne & 15 & 0 & 9 & 5 & 1 \\
\hline
\end{tabular}

Źródło: raport MPiPS

Czy zatem dentyści są pod tym względem grupą wyjątkową? By odpowiedzieć na to pytanie, autorzy postanowili zestawić powyższe dane z danymi dotyczącymi bezrobocia wśród innych, wybranych przykładowo zawodów i specjalności ich zdaniem również opartych na wiedzy. Okazuje się, że poziom bezrobocia wśród przedstawicieli tych zawodów jest znacznie większy. Przykładowo, zgodnie z danymi Izby Architektów RP, w 2011 r. uprawnionych do wykonywania tego zawodu było 9838 osób, a stopa bezrobocia pod koniec 2011 r. wynosiła wśród nich 9,39\%. Pomijając jednak rozważania na temat stopy bezrobocia wśród innych wybranych zawodów (dla większości z nich trudno znaleźć aktualne i wiarygodne dane dotyczące ich prawdziwej liczby), należy stwierdzić, że wśród wybranych zawodów opartych na wiedzy bezwzględna liczba bezrobotnych jest nieporównywalnie wyższa niż w przypadku dentystów. Znaczna część z nich pozostaje również bez pracy powyżej 12 miesięcy, co w przypadku dentystów prawie nie występuje (tab. 2). Z tego punktu widzenia, wśród analizowanych, najtrudniejszą sytuację na rynku pracy mają bezrobotni księgowi (stanowiący najliczniejszą grupę w analizowanej zbiorowości), wśród których 36,8\% nie pracuje powyżej roku, następnie optycy okularowi (29,8\%), testerzy oprogramowania komputerowego $(27,2 \%)$ oraz renowatorzy zabytków architektury $(26,3 \%)$. W przypadku pozostałych zawodów, bezrobotni pozostający bez pracy powyżej roku stanowią 14-19\% wszystkich bezrobotnych. Jednocześnie należy podkreślić, że liczba wolnych miejsc pracy oferowanych tym grupom bezrobotnych jest bardzo niska.

Porównując sytuację dentystów na rynku pracy z sytuacją wykonujących inne zawody oparte na wiedzy należy zatem stwierdzić, że jest ona dużo lepsza, a zjawisko bezrobocia wśród lekarzy stomatologów jest marginalne. 
Tab. 2. Zarejestrowani bezrobotni wśród wybranych zawodów i specjalności w końcu II półrocza $2011 \mathrm{r}$.

\begin{tabular}{|c|c|c|c|c|c|}
\hline \multirow[b]{2}{*}{ Zawody i specjalności } & \multirow{2}{*}{$\begin{array}{l}\text { Zarejestrowani } \\
\text { bezrobotni wg } \\
\text { stanu w końcu } \\
\text { II półrocza } \\
2011 \mathrm{r} \text {. }\end{array}$} & \multicolumn{3}{|c|}{$\begin{array}{l}\text { W tym bezrobotni poprzednio pra- } \\
\text { cujący według czasu pozostawania } \\
\text { bez pracy }\end{array}$} & \multirow{2}{*}{$\begin{array}{c}\text { Liczba } \\
\text { wolnych } \\
\text { miejsc pra- } \\
\text { cy i miejsc } \\
\text { aktywizacji } \\
\text { zawodowej } \\
\text { w końcu } \\
\text { II półrocza } \\
2011 \text { r. }\end{array}$} \\
\hline & & $\begin{array}{l}\text { do } \\
1 \text { mie- } \\
\text { siąca }\end{array}$ & $\begin{array}{l}\text { 1-12 mie- } \\
\text { sięcy }\end{array}$ & $\begin{array}{l}\text { pow. } 12 \\
\text { miesięcy }\end{array}$ & \\
\hline Architekt & 924 & 76 & 394 & 132 & 9 \\
\hline $\begin{array}{l}\text { Farmaceuta - farmacja } \\
\text { apteczna }\end{array}$ & 133 & 19 & 80 & 25 & 4 \\
\hline Geolog & 305 & 24 & 124 & 53 & 2 \\
\hline Inżynier geodeta & 107 & 8 & 44 & 16 & 0 \\
\hline Księgowy & 6781 & 497 & 3728 & 2496 & 190 \\
\hline Optyk okularowy & 104 & 13 & 49 & 31 & 1 \\
\hline Prawnik legislator & 2346 & 109 & 721 & 358 & 6 \\
\hline $\begin{array}{l}\text { Renowator zabytków } \\
\text { architektury }\end{array}$ & 300 & 22 & 158 & 79 & 0 \\
\hline $\begin{array}{l}\text { Tester oprogramowania } \\
\text { komputerowego }\end{array}$ & 493 & 27 & 213 & 134 & 1 \\
\hline
\end{tabular}

Źródło: raport MPiPS

\section{STOMATOLODZY A ZAKŁADANIE WŁASNEJ DZIAŁALNOŚCI GOSPODARCZEJ - WYNIKI BADAŃ WŁASNYCH}

W celu określenia uwarunkowań rozwoju usług dentystycznych w Polsce autorzy wykonali we wrześniu i październiku 2012 r. badania na grupie 60 lekarzy stomatologów. Z dotychczas przytoczonych przez autorów analiz wynikało, że rynek ten nie posiada ograniczeń: liczba klientów i ich zapotrzebowanie na usługi (pomimo ich znacznych jak na polskie zarobki cen) stale rośnie, kadra dentystów stale i powszechnie się dokształca, a problem bezrobocia wśród tej grupy zawodowej niemal nie występuje. Nadrzędnym celem przyświecającym badaniom stała się zatem odpowiedź na pytanie o ograniczenia w rozwoju tego specyficznego rynku.

Pierwszym etapem badań było przeprowadzenie pogłębionego wywiadu ze stomatologami prowadzącymi z powodzeniem praktykę dentystyczną od 2004 roku'. Celem było określenie zakresu potencjalnych zagrożeń, a następnie ich weryfikacja w dalszych badaniach na większej grupie badawczej. Wybrany przez autorów zakład stomatologiczny jest przykładem mikroprzedsiębiorstwa stomatologicznego, którego doświadczenie w prowa-

\footnotetext{
1 DentiMedical w Lubniu.
} 
dzeniu działalności potwierdziło wyniki wcześniejszych analiz. Badane przedsiębiorstwo jest firmą rodzinną, która początkowo zatrudniała zaledwie dwóch stomatologów-właścicieli i jedną osobę do pomocy technicznej. Prężne działania właścicieli spowodowały, że obecnie zatrudnia ono siedmiu lekarzy i cztery osoby do pomocy technicznej. Szybki rozwój przedsiębiorstwo to zawdzięcza stałemu podnoszeniu kwalifikacji personelu (uczestnictwu lekarzy we w sumie 40 szkoleniach, których średni koszt wynosił około 2000 zł), dzięki któremu zdecydowanie rozszerzono wachlarz świadczonych usług oraz stopień ich specjalizacji. Właściciele podjęli również skuteczne działania na rzecz pozyskiwania środków z funduszy unijnych na nowoczesne wyposażenie gabinetu. Informacje uzyskane w wywiadzie z właścicielami przedsiębiorstwa stały się punktem wyjścia dla przygotowania kwestionariusza ankiety do badania ograniczeń rynku stomatologicznego w Polsce, którym przebadano 60 lekarzy stomatologów.

Grupa ankietowanych lekarzy charakteryzowała się wysokim stopniem feminizacji. Wśród badanych $84 \%$ stanowiły kobiety, a zaledwie 16\% mężczyźni. Średnia wieku badanych kobiet wyniosła 32 lata, a mężczyzn 38 lat. Większość badanych dentystów to pracownicy $(65 \%)$, podczas gdy właściciele gabinetów stomatologicznych stanowili 33\% ankietowanych, a współwłaściciele 2\%. Warto dodać, że właściciele cechowali się wyższą średnią wieku (40 lat) niż pracownicy. Zdecydowana większość badanych stomatologów pracowała w mieście (84\%), zaledwie 9\% na wsi. Pozostała część ankietowanych wykonywała zawód równocześnie w mieście i na wsi, gdzie pracowali stomatolodzy o wyższej średniej wieku (40 lat) niż w miastach (33 lata).

W wyniku przeprowadzonych badań określono dwie bariery ograniczające rozwój rynku usług stomatologicznych w Polsce. Pierwsze ograniczenie związane jest z brakiem wiedzy proceduralnej dotyczącej zakładania i prowadzenia przedsiębiorstw. Drugim czynnikiem są wysokie koszty rozpoczęcia tego typu działalności gospodarczej.

Wśród badanych stomatologów $65 \%$ osób prowadziło własną działalność gospodarczą w postaci gabinetu stomatologicznego. Wśród właścicieli zdecydowana większość (ok. 70\%) prowadziła działalność gospodarczą w mieście, a pozostała część na wsi. Średni wiek pracodawców był wyższy od średniego wieku pracowników i wynosił 37,2 lat. Posiadali oni również niemal trzykrotnie dłuższy od pracowników staż pracy, średnio 12,7 lat w zawodzie. Wśród prowadzących działalność dominowali mężczyźni (75\%).

W badaniach autorzy skupili się na umiejętnościach i wiedzy dentystów w zakładaniu i prowadzeniu własnej działalności gospodarczej. Zgodnie z deklaracjami badanych, 70\% dentystów zna procedurę zakładania działalności gospodarczej. Wynika z tego, że oprócz prowadzących własne gabinety stomatologiczne, wśród pozostałych ankietowanych tylko 1/7 posiada taką wiedzę. Jeszcze gorsze wyniki przyniosła odpowiedź na pytanie o umiejętność prowadzenia tego typu działalności. Wiedzę taką posiadają tylko osoby prowadzące własną działalność. A zatem Ci stomatolodzy, którzy już przeszli procedurę rejestracji i prowadzą działalność deklarują, że posiadają umiejętności w tym zakresie. Niewielki jest również odsetek chcących założyć działalność wśród tych, którzy jej nie prowadzą, za to już prowadzący zgodnie deklarują, że chcieliby rozszerzyć zakres działalności swojego gabinetu. Brak wiedzy na temat zakładania i prowadzenia działalności gospodarczej bierze 
się z dwóch źródeł. Jednym z nich jest zapewne bardzo dobra sytuacja dentystów na rynku pracy, która nie wymusza na nich poszukiwania form samozatrudnienia, z drugiej zaś strony brak jest kształcenia w tym zakresie oferowanego ze strony szkoły. Według ankiety $88 \%$ badanych stwierdza bowiem, że wiedzy na temat zakładania działalności gospodarczej nie zdobyła w trakcie nauki szkolnej.

Skąd zatem wiedza na temat zakładania działalności jest czerpana przez tych, którzy zdeklarowali, że potrafiliby taką działalność założyć? Okazuje się, że $29 \%$ z nich wiedzę na temat zakładania działalności czerpie od rodziny lub znajomych. Wskazuje to na duże powiązania rodzinne w zakresie wykonywania zawodu lekarza oraz potwierdza duże znaczenie nieformalnych kontaktów w działalności gospodarczej. Niemal tyle samo (27\%) uzyskuje ją z Internetu, podczas gdy tylko $20 \%$ z fachowej literatury. Fakt ten zwraca uwagę na coraz większe znaczenie Internetu i specjalistycznych portali internetowych, z których korzysta coraz więcej, głównie młodych ludzi. Natomiast z dodatkowych kursów lub szkoleń na temat zakładania i prowadzenia własnej działalności gospodarczej skorzystało ok. 26\% ankietowanych. Tak mała liczba osób korzystających z tej formy kształcenia może być spowodowana najmniejszą jej dostępnością spośród wszystkich wcześniej wymienionych form (koszty i lokalizacja kursów) oraz małą ofertą tego rodzaju szkoleń.

Warto nadmienić, że osoby, które uczestniczyły w kursach lub szkoleniach niemal jednogłośnie twierdzą, że wiedza zdobyta tam była bardzo pomocna (90\%). Ważną kwestią w zakładaniu działalności stomatologicznej, wynikającą z przeprowadzonych przez autorów badań wstępnych, jest również wiedza na temat pozyskiwania środków, w szczegolności z funduszy unijnych, na wyposażenie gabinetów i rozpoczęcie działalności. Zgodnie z wynikami badań, wśród dentystów niewiele ponad połowa (56\%) posiada wiedzę na temat źródeł pozyskiwania funduszy inwestycyjnych.

W ocenie badanych stomatologów wiedza na temat zakładania i prowadzenia własnej działalności gospodarczej powinna być przekazywana w trzech miesiącach. Połowa badanych stwierdza, że powinna być ona przekazywana na szkoleniach, a druga połowa uznaje, że powinni ją uzyskać już w trakcie edukacji. Większość ze zwolenników wyposażenia w wiedzę z zakresu samozatrudnienia w trakcie nauki uważa, że powinna być ona przekazywana na studiach (44\% badanych), a $6 \%$ uznaje, że powinna być ona przedmiotem rozważań na niższych etapach edukacyjnych. Miejsce i charakter szkoleń z zakresu szeroko rozumianej przedsiębiorczość, zostały podkreślone przez władze europejskie, umieszczające przedsiębiorczość w kluczowych kompetencjach w europejskim obszarze edukacyjnym (Dorocki, Kilar, Rachwał 2011).

\section{PRZEKROCZENIE BARIERY PIERWSZEJ - OFERTA SZKOLENIOWA}

Odpowiedzią na zapotrzebowanie związane z brakiem wiedzy i umiejętności, szczególnie z zakresu umiejętności „miękkich” - związanych z zakładaniem działalności gospodarczej i zarządzaniem własną praktyką stomatologiczną, są oferowane kursy i szkolenia. 
Spośród oferowanych na rynku szkoleń, szeroką gamą ofert wyróżnia się Polska Agencja Rozwoju Przedsiębiorczości (PARP). Jest to powstała w 2000 roku instytucja państwowa, której zadaniem jest wspieranie, stymulowanie i kreowanie: przedsiębiorczości, innowacyjności i rozwoju zasobów ludzkich. W przeprowadzonej analizie tematyki oferowanych do 2012 roku 1332 kursów i szkoleń realizowanych na terenie całego kraju, wyróżniono tylko 5 tematów związanych z zakładaniem własnej działalności gospodarczej. Szkolenia te były jednak bardzo ograniczone geograficznie i skierowane tylko do wybranych miast i powiatów, głównie południowej Polski. Równocześnie szkolenia były przeznaczone głównie dla grup osób o ograniczonym potencjale przedsiębiorczym. W złożeniach głównymi beneficjentami szkoleń były osoby bezrobotne, starsze oraz kobiety w wieku przedemerytalnym. Tylko w dwóch szkoleniach mogły uczestniczyć (w miarę pozostawania wolnych miejsc) osoby nie zaliczające się do wskazanych grup społecznych, jednakże związane było to z uiszczeniem opłaty, której wysokość wynosiła ok. 5 tys. złotych. Tak więc pomimo w miarę dużej ilości proponowanych usług szkoleniowych przez PARP, brak jest oferty skierowanej do osób przedsiębiorczych posiadających już wiedzę i umiejętności do wykonywania swojego zawodu, lecz potrzebujących pomocy związanej z rozwijaniem własnej działalności gospodarczej. Szkolenia przeznaczone dla osób bezrobotnych są wg wielu analityków postrzegane jako mało wydajne, kreujące postawy roszczeniowe w społeczeństwie oraz osłabiające własną inicjatywę wśród bezrobotnych (Borowiec 2006). Dzieje się tak, gdyż organizowane przez instytucje państwowe szkolenia są często przymusowe (uczestnictwo w nich warunkuje otrzymanie dalszych świadczeń socjalnych i finansowych). Z drugiej strony inwestycje w ludzi, poprzez podnoszenie ich kwalifikacji, są jednymi z najbardziej wydajnych lokat finansowych i są najlepszym narzędziem aktywizacji gospodarczej (Dorocki, Jenner 2009). Wydaje się zatem właściwe, aby oferty szkoleniowe nie były kierowane tylko do zagrożonych bezrobociem grup społecznych, ale głównie do osób charakteryzujących się postawami przedsiębiorczymi, gdyż w ten sposób mamy największą szansę na generowanie rozwoju gospodarczego różnej wielkości jednostek przestrzennych (Wach 2010). Osoby przedsiębiorcze, dostając szansę na założenie własnej działalności gospodarczej, dają większą gwarancję jej przetrwania na konkurencyjnym rynku i zapewnią wzrost poziomu zatrudnienia poprzez tworzenie miejsc pracy. Dodatkowo należy zaznaczyć, że głównymi beneficjentami takich szkoleń powinni być również specjaliści i pracownicy z innowacyjnych sektorów gospodarki. Inwestycje w przemysł i usługi związane z nowymi technologiami wydają się przynieść w przyszłości największe korzyści rozwojowe. Zapewnią również stabilność inwestycji w dłuższym okresie czasu, gdyż nowoczesne działy gospodarki są w najmniejszym stopniu narażone na niebezpieczeństwa związane ze schyłkiem branży.

W oparciu o powyższe tezy wydaje się, że lepszym rozwiązaniem od ogólnych kursów PARP są realizowane w ramach utworzonego w 1996 roku Krajowego Systemu Usług (KSU) programy informacyjne i doradcze skierowane do przedsiębiorców i osób zamierzających rozpocząć działalność gospodarczą. Na uwagę zasługują bezpłatne oferty informacyjne skierowane dla początkujących przedsiębiorców oraz dotowane usługi doradcze i asysta w prowadzeniu działalności gospodarczej. Wśród ofert KSU na uznanie zasługuje program „Wsparcie dla nowych firm”, w którym udzielana jest pomoc informacyjna na temat: jak 
założyć własną firmę (szczegółowa informacja o wymaganych dokumentach i działaniach) dobierając jej optymalną formę prawną i rodzaj opodatkowania. Obok bezpłatnych ofert informacyjnych, KSU oferuje płatną usługę doradczą (w 90\% refundowaną przez państwo), z zakresu konsultacji profilu planowanej działalności gospodarczej lub pomocy w przygotowaniu biznesplanu i zgromadzeniu niezbędnej dokumentacji. Dodatkowo oferowana jest płatna asysta w prowadzeniu działalności gospodarczej z zakresu formalno-prawnych obowiązków związanych z funkcjonowaniem firmy lub korzystania ze źródeł finansowania dedykowanych przedsiębiorcom. Dodatkowo Akademia PARP oferuje interaktywne szkolenia on-line w wersji elektronicznej, w ramach których poruszane są zagadnienia z zakresu wiadomości na temat zakładania i funkcjonowania własnej firmy.

Przedstawione powyższej dwie wybrane oferty realizowane przez Agencję wydają się ciekawym rozwiązaniem dla przyszłych przedsiębiorców-dentystów. Zwraca uwagę wykorzystanie innowacyjnych technologii oraz duża elastyczność prowadzonych działań poprzez podejście indywidualne do potencjalnego przedsiębiorcy w przypadku usług doradczych KSU. Prowadzone badania wykazały jednak, że duża część osób zamierzająca rozpocząć działalność gospodarczą nie posiadała wiedzy na temat możliwości skorzystania z powyższych ofert.

W drugiej części analizy rynku szkoleń podjęto tematykę szkoleń skierowanych wyłącznie do pracowników służby zdrowia. Wśród oferowanych szkoleń wyróżniają się usługi oferowane przez Naczelną Izbę Lekarską (NIL). Spośród ofert szkoleniowych Izby z zakresu kursów pozamedycznych dla lekarzy-przedsiębiorców wyróżnić można szkolenia z zakresu: mediacji, skutków prawnych w aspekcie odpowiedzialności lekarzy, prawa pracy w przedsiębiorstwach leczniczych, obrony i zastępowania lekarza przed sądami powszechnymi. Ponadto oferowane są szkolenia z zakresu wystawiania recept i ich refundacji, odpowiedzialności lekarza za źle wystawione recepty, zwrotu refundacji. Oferowane są również kursy na temat uregulowania kontaktów z przedstawicielami medycznymi i z samorządem lekarskim. Innymi przydatnymi ofertami są warsztaty skutecznych negocjacji, kierowanie zespołem i praca w zespole, analiza transakcyjna jako metoda reagowania na zachowania agresywne oraz psychomanipulacja. Lista szkoleń oferowanych przez NIL dotyczy zatem zarówno kwestii zawodowych lekarzy związanych ze specyfiką zawodu, jak i zawiera również ofertę warsztatów o tematyce związanej z funkcjonowaniem w zespole oraz kształtowaniem umiejętności i postaw przydatnych na rynku pracy. Brak jest natomiast kursów poświęconych zakładaniu i funkcjonowaniu gabinetów lekarskich jako podmiotów gospodarczych oraz szkoleń związanych z wymogami jakie stawiane są przed osobami planującymi założyć własne praktyki i gabinety lekarskie.

Szkolenia praktyczne dla lekarzy prowadzących lub planujących założyć własną działalność gospodarczą, można odnaleźć wśród ofert prywatnych firm szkoleniowych. Proponowane dla rynku medycznego kursy obejmują tematycznie m.in. kształtowanie wzrostu poziomu satysfakcji pacjentów z leczenia, zwiększanie liczby i jakości rekomendacji, wzrost efektywności pracy, zwiększanie liczby kompleksowych leczeń oraz ograniczanie liczby odkładanych i niedokończonych leczeń. Inne tematy szkoleń to techniki mobilizowania pacjentów do systematycznych wizyt kontrolnych oraz zarządzanie sobą, emocjami 
i zespołem. Są to oferty zarówno dla lekarzy, jak i personelu medycznego. Szkolenia te są jednak skierowane do lekarzy bez rozróżnienia ich specjalizacji i typu pracy oraz odnoszą się do kształtowania ogólnych umiejętności. Brak jest w ofercie szkoleń specjalistycznych, uwzględniających specyfikę wykonywanych usług medycznych. W dalszych analizach skupiono się na poszukiwaniu i analizie szkoleń skierowanych do pracowników sektora stomatologicznego. Spośród przeanalizowanych 555 szkoleń dla dentystów w okresie roku, od 10.2011 do 10.2012, 65 szkoleń było oferowanych przez NIL, a pozostałe przez firmy prywatne. Szkolenia prowadzone były w 66 miastach, głównie Warszawie (210 szkoleń) i największych miastach Polski (ryc. 3A). Jednakże tylko ok. 8\% szkoleń odnosiło się do zagadnień szeroko rozumianego zarządzania i przedsiębiorczości (ryc. 3B).
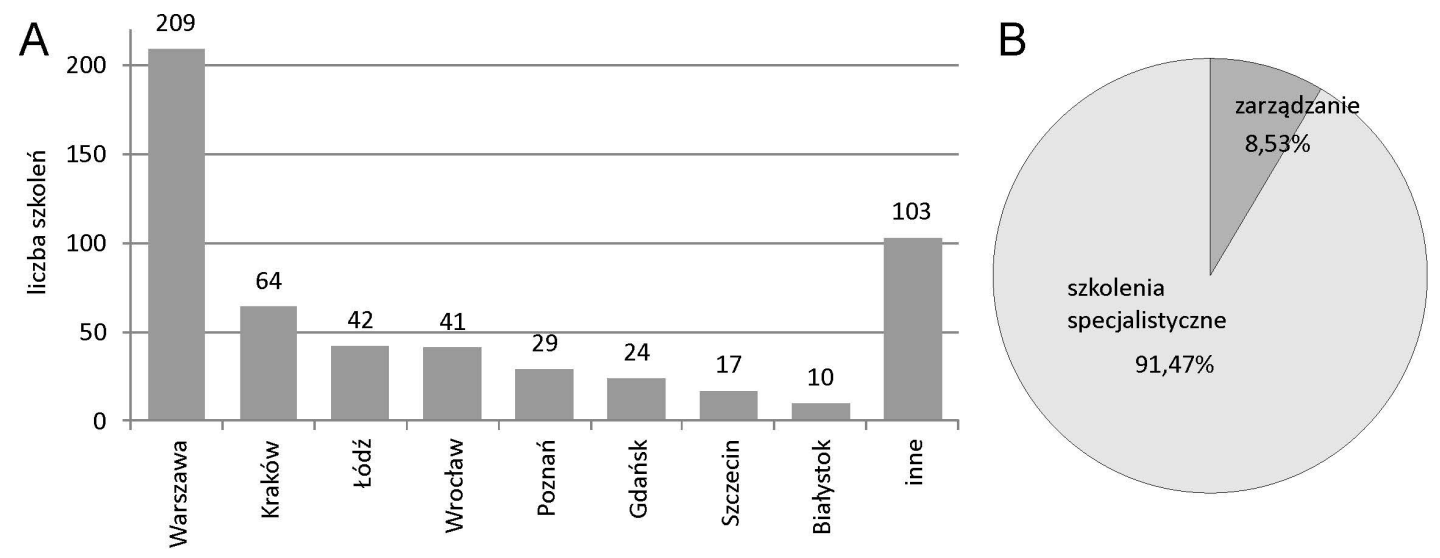

Ryc. 3. Liczba i miejsce szkoleń skierowanych dla dentystów w okresie X 2011-X 2012

(A) oraz tematyka tych szkoleń (B)

Źródło: opracowanie własne na podstawie kwerendy stron internetowych

W wyniku dokonanych badań i analiz należy zatem stwierdzić, że oferowane przez wskazane instytucje szkolenia nie odpowiadają w zadowalającym zakresie potrzebom potencjalnych przedsiębiorców-stomatologów i stanowią niniejszym potwierdzenie dla realnie występującej bariery w rozwoju usług stomatologicznych opartych na wiedzy.

\section{BARIERA DRUGA - KOSZTY ZAKŁADANIA GABINETU DENTYSTYCZNEGO}

Drugą wykrytą w toku badań barierą w rozwoju rynku stomatologicznego w Polsce jest wysoki koszt założenia tego typu działalności i związane z nią skomplikowane wymogi prawno-proceduralne. Autorzy, by określić znaczenie tej bariery, dokonali zestawienia kosztów, jakie muszą ponieść dentyści rozpoczynający działalność gospodarczą. Celem była odpowiedź na pytanie, czy tak jak wykazywało w ankietach wielu, zazwyczaj młodych, dentystów, nie otworzenie własnego gabinetu związane jest $\mathrm{z}$ barierami finansowymi. Według dokonanych przez autorów wywiadów i analizy ofert firm wyposażających i dostosowujących 
lokale do prowadzenia gabinetów dentystycznych okazuje się, że koszt rozpoczęcia tego typu działalności to 150-200 tys., bez uwzględnienia opłat związanych z warunkami lokalowymi, które wykazują duże zróżnicowanie geograficzne oraz możliwość uruchomienia gabinetu w mieszkaniu prywatnym. Największe wydatki należy ponieść w celu dostosowania lokalu do wymogów sanitarnych, zakup unitu stomatologicznego oraz dokonanie potrzebnych prac budowlanych. Innymi niezbędnymi urządzeniami są sterylizator stomatologiczny oraz narzędzia i materiał dentystyczny. Uwzględniając możliwości leasingowe (które w praktyce dentystycznej są bardzo duże) (Żądło 2009) oraz ograniczając zakres wykonywanych zabiegów dentystycznych (m.in. w ramach współpracy z Practice Limited to Endodontics), według praktyków można obniżyć koszty sprzętowo-adaptacyjne do 50 tys. zł oferując podstawowe zabiegi dentystyczne. Istnieje również możliwość zakupu używanego sprzętu i tu ceny wahają się od 20-25 tysięcy za pełne wyposażenie gabinetu. Również materiały dentystyczne (sterylizacja, zużycie wierteł, materiały wypełniające i leki), które stanowią średnio ok. 30\% (70\% to zysk i koszty stałe) kosztów zabiegu dla pacjenta, mogą być uzupełnianie w miarę zapotrzebowania na nie, dzięki czemu można nie wliczać ich w potrzebny „na start” kapitał. Wydaje się zatem, że ograniczenia finansowe nie są istotną barierą dla rozpoczęcia działalności i w dużej mierze mogą być zaspokojone środkami oferowanymi w ramach publicznych programów wspomagających przedsiębiorczość. Dodatkowo trzeba zaznaczyć, że gabinety dentystyczne często stanowią jeden z nielicznych podmiotów przemysłu i usług innowacyjnych na terenach wiejskich. Wiąże się to z większymi szansami na pozyskanie dotacji unijnych na rozwój nowych technologii. Dlatego też wydaje się właściwe stwierdzenie dentystów z dłuższą praktyką, że głównym uwarunkowaniem funkcjonowania gabinetu stomatologicznego jest wiedza, zarówno zawodowa, jaki i odnosząca się do zagadnień ekonomicznych, ze szczególnym podkreśleniem tej dotyczącej procedury zakładania i prowadzenia działalności gospodarczej.

\section{Podsumowanie}

Na podstawie przeprowadzonych przez autorów badań i analiz w artykule dokonano charakterystyki uwarunkowań usług stomatologicznych w Polsce, jako przykładu usług opartych na wiedzy. Zgodnie z uzyskanymi wynikami badań należy stwierdzić, że uwarunkowania usług opartych na wiedzy należy podzielić na uwarunkowania wewnętrzne (zależne od charakteru grupy zawodowej badanych) oraz na uwarunkowania zewnętrzne (w skład których należy zaliczyć sytuację na danym rynku usług oraz narzędzia wspierające jego rozwój).

Wśród uwarunkowań wewnętrznych największe znaczenie ma podejście grup zawodowych do doskonalenia zawodowego, zapewniającego stałe oparcie świadczonych usług na aktualnej wiedzy oraz umiejętność odpowiedzi na zmieniające się potrzeby rynku. W tym przypadku grupa badanych lekarzy stomatologów wypada bardzo dobrze, charakteryzując się wysoką świadomością konieczności kształcenia ustawicznego, w szczególności w zakresie zdobywania coraz to nowszej wiedzy specjalistycznej oraz ponosząc znaczne koszty 
czasowe i finansowe na własny rozwój. Ważną, wykazaną cechą stomatologów prowadzących działalność gospodarczą jest również aktywna odpowiedź na zapotrzebowanie rynku, objawiająca się rozszerzaniem ofert usług stomatologicznych (której konsekwencją jest przymus stałego podnoszenia kwalifikacji). Wykazanym w toku badań ograniczeniem w tym zakresie jest niska wiedza stomatologów na temat zakładania i prowadzenia własnej działalności gospodarczej oraz niski odsetek osób planujących takową założyć. Świadczyć to może o niepokojącym braku przedsiębiorczości tej grupy zawodowej, silnie pochłoniętej podnoszeniem własnych kwalifikacji. Trzecią i ostatnią barierą wewnętrzną jest wysokość posiadanych przez stomatologów środków na założenie własnej działalności.

Drugą grupą uwarunkowań rozwoju usług opartych na wiedzy, w tym usług stomatologicznych w Polsce, są uwarunkowania zewnętrzne. Wśród nich, na szczególną uwagę zasługują: wielkość i charakter rynku danych usług, wymogi prawne dotyczące zakładania danego typu działalności, rynkowy koszt jej założenia oraz system przygotowania potencjalnych przedsiębiorców do zakładania i prowadzenia danego typu działalności (w tym dostępne wsparcie merytoryczne i finansowe instytucji państwowych oraz prywatnych). W przypadku rynku usług stomatologicznych koniunktura jest bardzo dobra. Klienci coraz powszechniej korzystają z usług podstawowych i wykazują zwiększone zapotrzebowanie na coraz to nowsze usługi. Pojawiają się również nowe możliwości w postaci zwiększenia rynku o klientów zagranicznych. Pozytywnym aspektem jest również bardzo korzystna sytuacja stomatologów na rynku pracy, potwierdzająca wysokie zapotrzebowanie na świadczone przez nich usługi. Istnieją jednak uwarunkowania zewnętrzne wpływające negatywnie na rozwój usług stomatologicznym na polskim rynku. Wśród nich należy wskazać ograniczoną ofertę szkoleniową skierowaną do chcących założyć tego typu działalność gospodarczą, skomplikowane procedury urzędowe oraz niesprzyjające rozwojowi prawo sanitarne i prawo ochrony zdrowia. Ostatnim wskazanym przez autorów ograniczeniem są wysokie koszty zakładania tego typu działalności. Ograniczenia finansowe są jednak typowe dla wielu rodzajów działalności, niekoniecznie opartych na wiedzy.

Przeprowadzone badania i analizy, które wymagają oczywiście kontynuacji, już na tym etapie pracy wykazały, że wbrew pozorom czynnikami warunkującymi rozwój usług opartych na wiedzy mogą być przyczyny bardzo prozaiczne. Tak jest w przypadku badanego rynku stomatologów. Główną barierą w rozwoju tych usług opartych na wiedzy (oprócz oczywistej dla większości działalności bariery finansowej), okazała się być nie wiedza specjalistyczna czy medyczna, lecz zwykła wiedza z zakresu zakładania i prowadzenia działalności gospodarczej. Wniosek ten, zdaniem autorów, powinien być kolejnym przyczynkiem do skupienia się przez władze państwowe na kształtowaniu postaw przedsiębiorczych i przekazywaniu wiedzy z zakresu przedsiębiorczości w toku edukacji szkolnej. 


\section{Literatura / References}

Borowiec, M. (2006). Etyczne aspekty globalizacji w procesie kształtowania przedsiębiorczości. Przedsiębiorczość - Edukacja, 2, 185-192.

Borowiec, M., Dorocki, S., Jenner, B. (2009). Wpływ zasobów kapitału ludzkiego na kształtowanie społeczeństwa informacyjnego i innowacyjności struktur przemysłowych. Prace Komisji Geografii Przemystu Polskiego Towarzystwa Geograficznego, 13, 95-109.

Dorocki, S., Jenner, B. (2009). Wpływ wielkości nakładów inwestycyjnych w sektorze B+R na regionalne zróżnicowanie tempa rozwoju Francji. Przedsiębiorczość - Edukacja, 5, 188-197.

Dorocki, S., Kilar, W., Rachwał, T. (2011). Założenia i cele Projektu „Krok w przedsiębiorczość” dla nauczycieli szkół ponadgimnazjalnych. Przedsiębiorczość - Edukacja, 7, 308-320.

Dziennik Gazeta Prawna, 2011-02-16.

Dziennik Gazeta Prawna, 2011-02-20.

Gazeta Wyborcza, 2012-02-27.

OECD 1996. The Knowledge-Based Economy. Paris, GD 102.

Raport Instytutu Filozofii i Socjologii PAN i Ośrodka Studiów, Analiz i Informacji NIL: Możliwości i bariery rozwoju zawodowego lekarzy i lekarzy dentystów. Warszawa 2012.

Raport MPiPS, Departament Rynku Pracy: Zarejestrowani bezrobotni oraz wolne miejsca pracy i miejsca aktywizacji zawodowej wg zawodów i specjalności w II półroczu 2011 roku. Warszawa 2012.

Rogut, W. (2011). Dentyści ruszają po wiedzę. Stużba Zdrowia, 85-92 (4086-4093).

Strona Internetowa Naczelnej Izby Lekarskiej: http://www.nil.org.pl/.

Wach, K. (2010). Ewolucja europejskiej polityki wspierania przedsiębiorczości w latach 1973-2013. Prace Naukowe Uniwersytetu Ekonomicznego we Wrocławiu, seria Ekonomia, 113, 1003-1019.

Żądło, J. (2009). Leasing jako źródło kapitału inwestycji. Niepublikowana praca dyplomowa pod kierunkiem naukowym dr D. Podedwornej-Tarnowskiej. Warszawa: Szkoła Główna Handlowa w Warszawie.

Sławomir Dorocki, dr, Uniwersytet Pedagogiczny w Krakowie, Instytut Geografii, Zakład Przedsiębiorczości i Gospodarki Przestrzennej.

Absolwent studiów z zakresu geografii społeczno-ekonomicznej Uniwersytetu Pedagogicznego w Krakowie, doktor nauk humanistycznych w dyscyplinie historia (Instytut Europeistyki - Uniwersytet Jagielloński). Adiunkt w Instytucie Geografii Uniwersytetu Pedagogicznego w Krakowie. Zainteresowania badawcze autora skupiają się wokół problematyki regionów i procesów regionalizacji społeczno-gospodarczej, ze szczególnym uwzględnieniem zróżnicowania przestrzeni europejskiej oraz procesów integracji europejskiej i uwarunkowań historycznych.

Sławomir Dorocki, Ph.D., Pedagogical University of Cracow, Institute of Geography, Department of Entrepreneurship and Spatial Management.

Graduated from Pedagogical University in Cracow MA degree in Geography, Ph.D. in History (Institute of European Studies of the Jagiellonian University). Senior Lecturer at Pedagogical University of Cracow, Institute of Geography. His research interests focus on regional problems and processes of socio-economic regionalization, with particular emphasis on the diversity of Europe, processes of European integration and historical conditions.

Agnieszka Świętek, mgr, Uniwersytet Pedagogiczny w Krakowie, Instytut Geografii, Zakład Dydaktyki Geografii.

Absolwentka studiów z zakresu geografii Uniwersytetu Pedagogicznego w Krakowie w specjalności Przedsiębiorczość i gospodarka przestrzenna. Asystent w Instytucie Geografii Uniwersytetu 
Pedagogicznego w Krakowie. Jej zainteresowania badawcze skupiają się wokół dwóch tematów: problematyki edukacji z zakresu geografii i przedsiębiorczości, a w szczególności procesu zakładania własnej działalności gospodarczej oraz poziomu życia Romów w Polsce.

Agnieszka Świętek, MA, graduated from Pedagogical University in Cracow MA degree in geography, specialization in Entrepreneurship and spatial planning. Assistant at Pedagogical University of Cracow, Institute of Geography. Her research interests focus on two different research themes: the education in the field of geography and entrepreneurship, in particular the process of starting up own business, and the quality of life of Roma in Poland.

adres/address: Uniwersytet Pedagogiczny w Krakowie

Instytut Geografii, ul. Podchorążych 2, 30-084 Kraków, Polska

e-mail: sdorocki@up.krakow.pl (Sławomir Dorocki)

swietekaga@wp.pl (Agnieszka Świętek) 